\section{Effect of Fungicides and Miticides with Mitochondria Electron Transport Inhibiting Activity on the Twospotted Spider Mite, Tetranychus urticae (Acari: Tetranychidae)}

\author{
Raymond A. Cloyd ${ }^{1}$ \\ Department of Entomology, Kansas State University, 123 Waters Hall, \\ Manhattan, KS 66506-4004
}

Cindy L. Galle and Stephen R. Keith

AllTech Research and Development, Sparta, IL 62286

Kenneth E. Kemp

Department of Statistics, Kansas State University, Manhattan, KS 66506

Additional index words. acequinocyl, pyridaben, fenpyroximate, azoxystrobin, kresoximmethyl, trifloxystrobin

\begin{abstract}
The twospotted spider mite, Tetranychus urticae, is a major arthropod pest of many greenhouse-grown horticultural crops. Greenhouse producers use a variety of miticides to suppress twospotted spider mite populations. A group of miticides known as mitochondria electron transport inhibitors or METIs include acequinocyl, fenpyroximate, and pyridaben. In addition, there are strobilurin-based fungicides such as azoxystrobin, kresoxim-methyl, and trifloxystrobin that are also known as METIs. We conducted a study to determine if these METI fungicides had any miticidal properties against the nymph and adult stages of the twospotted spider mite. The designated treatments were applied to marigold (Tagetes erecta) plants naturally infested with twospotted spider mites. Assessments of live and dead twospotted spider mite nymphs and adults were conducted 3, 7, and 14 days after applying the treatments. None of the METI fungicides had any activity against the nymph and adult life stages of the twospotted spider mite, with percentage mortality values $<\mathbf{1 8 \%}$. The METI miticides appeared to be more effective against twospotted spider mite nymphs than the adults based on percentage mortality values across the three evaluation periods $(35.2 \%$ to $100 \%$ for nymphs and $11.4 \%$ to $87.9 \%$ for adults). This study demonstrated that the strobilurin-based fungicides have negligible negative effects on twospotted spider mites.
\end{abstract}

The twospotted spider mite, Tetranychus urticae (Acari: Tetranychidae), is one of the most destructive mite pests of greenhousegrown horticultural crops, feeding on over 300 plant species (Jeppson et al., 1975; van de Vrie, 1985), and, as such, greenhouse producers use a variety of miticides to alleviate problems and avoid twospotted spider mite outbreaks (Brodsgaard and Albajes, 1999; van Leeuwen et al., 2004). There are a number of commercially available miticides that are known as mitochondria electron transport inhibitors or METIs (Ware and Whitacre, 2004;

Received for publication 17 Dec. 2009. Accepted for publication 16 Feb. 2010.

We thank Dr. David C. Margolies and Dr. Kun Yan Zhu (Department of Entomology, Kansas State University, Manhattan, KS) for reviewing earlier drafts of the manuscript. We also wish to thank the four anonymous reviewers whose feedback was valuable in developing the final version of the manuscript.

${ }^{1}$ To whom reprint requests should be addressed; e-mail rcloyd@ksu.edu.
1995; Yu, 2008). The basic difference between these modes of action is the target site; acequinocyl is active on complex III, whereas pyridaben and fenpyroximate are active on complex I (Dekeyser, 2005; Yu, 2008).

The strobilurin-based or $\mathrm{Q}_{\mathrm{o}}$-inhibiting fungicides (Fungicide Resistance Action Committee Code 11) such as azoxystrobin (Heritage; Syngenta Crop Protection, Greensboro, NC), kresoxim-methyl (Cygnus; BASF Corp., Research Triangle Park, NC), and trifloxystrobin (Compass; OHP, Inc., Mainland, PA) are considered METIs with activity on complex III in the mitochondria of many different fungi (Gisi et al., 2002; Wood and Hollomon, 2003). Although spider mites and fungi are in different biological kingdoms, we considered it prudent to quantitatively determine if these fungicide types have miticidal properties such as controlling the nymph and/or adult stages of the twospotted spider mite. The strobilurin-based fungicides also possess translaminar properties (Cloyd 2003); however, it is not known how this may influence mite feeding because a number of commercially available miticides have translaminar activity.

Certain fungicides have been shown to provide control or to suppress populations of spider mites (Biggs and Hagley, 1988; Bower et al., 1995). For example, older fungicides such as sulfur, benomyl, manzate, and dinocap were demonstrated to suppress populations of phytophagous mites (Lord, 1949; Morgan et al., 1958; Childers and Enns, 1975). The benzimidazole systemic fungicide, benomyl, which is no longer commercially available for use in ornamental cropping systems, has been shown to inhibit the development of twospotted spider mite directly as well as reducing female fecundity (Delp and Klopping, 1968; Spadafora and Lindquist, 1972; Poe and McFadden, 1972; Alston and Thomson, 2004). However, the strobilurin-based fungicide trifloxystrobin was not toxic to female twospotted spider mites (Alston and Thomson, 2004). If the strobilurin-based fungicides displayed sufficient miticidal activity ( $>70 \%$ mortality), it could possibly lead to greenhouse producers using only one product for fungal and spider mite suppression. Therefore, the objective of this study was to compare the efficacy and residual activity of METI miticides with several METI fungicides against the twospotted spider mite.

\section{Materials and Methods}

We conducted a study at a research facility (AllTech Research and Development, Sparta, IL) to determine the efficacy of miticides and fungicides with activity on the mitochondria on the nymphal and adult stages of the twospotted spider mite. Untreated marigold (Tagetes erecta 'Antiqua Yellow') plants in the vegetative stage were transplanted into 0.9-L containers filled with Fafard $3 \mathrm{~B}$ growing medium consisting of peatmoss, perlite, vermiculite, and processed pine bark (Conrad Fafard, Inc., Agawam, MA). The marigold test plants were placed into a greenhouse 
containing marigolds already infested with twospotted spider mite to allow a "natural" population of mites to infest and build up on the marigolds (about 2 weeks) to be used in the study. The treatments used in the study were acequinocyl (Shuttle; OHP, Inc.), fenpyroximate (Akari 5SC; SePRO), pyridaben (Sanmite; Gowan), azoxystrobin (Heritage; Syngenta Crop Protection, Inc.), kresoximmethyl (Cygnus; BASF), and trifloxystrobin (Compass; OHP, Inc.). Two additional miticides with different modes of action were used as standard controls; spiromesifen (Judo; OHP, Inc.) and clofentezine (Ovation; Scotts-Sierra Crop Protection Comp., Marysville, $\mathrm{OH})$. The treatments and application rates are presented in Table 1. For the miticides, we used the recommended label rates for twospotted spider mite. The fungicide rates used were based on the recommended label rate for the designated diseases such as powdery mildew, rusts, and downy mildew for which these fungicides are labeled. An untreated control and water control were also included. There were five replications or plants per treatment. Treatments were applied using a fine mist spray bottle that thoroughly saturated the test plants but did not result in significant runoff. The marigolds were $\approx 30.5$ $\mathrm{cm}$ in height at the time of application. After applying the treatments, the test plants were placed into another research greenhouse on a wire-mesh raised bench and were arranged in a completely randomized design. The temperature in the greenhouse ranged from $30{ }^{\circ} \mathrm{C}$ (day) to $22{ }^{\circ} \mathrm{C}$ (night) with a relative humidity between $50 \%$ and $90 \%$. Test plants received natural lighting during the course of the study. All marigold plants were watered with a handheld irrigation wand directed at the growing medium; there was no overhead irrigation to avoid washing off any twospotted spider mites.

Plants were evaluated before application of the treatments (precount), and 3, 7, and 14 $\mathrm{d}$ after treatment. Four leaves were randomly selected and harvested from each plant. The number of live and dead nymphs, and live and dead adults of twospotted spider were recorded. The precount reading was performed to ensure that the test plants had uniform populations of twospotted spider mites so that any effects were solely due to the treatments and were not confounded with variable numbers of twospotted spider mites on the marigolds. Furthermore, we observed that dead twospotted spider mites adhered to the leaf surface and did not fall off the plants.

Statistical analysis. We used Abbott's correction mortality (Abbott, 1925), based on the water control, to the proportions of dead twospotted spider mite nymphs and adults to adjust the mortality estimates, and we then

Table 1. The common name (a.i.), percentage a.i., trade name, mode of action code designation, and rate of the mitochondria electron transport inhibiting (METI) miticides and fungicides, and other miticides evaluated in the study for control of the twospotted spider mite, Tetranychus urticae.

\begin{tabular}{|c|c|c|c|c|}
\hline $\begin{array}{l}\text { Treatment } \\
\text { common name }\end{array}$ & $\begin{array}{c}\text { Percentage of } \\
\text { active ingredient }\end{array}$ & $\begin{array}{l}\text { Trade } \\
\text { name }\end{array}$ & $\begin{array}{l}\text { FRAC/IRAC } \\
\text { code }\end{array}$ & Label rate \\
\hline \multicolumn{5}{|l|}{ METI miticides } \\
\hline Acequinocyl & $15.8 \%$ & Shuttle & $20 \mathrm{~B}$ & $295.7 \mathrm{~mL} / 378.5 \mathrm{~L}$ \\
\hline Fenpyroximate & $5.0 \%$ & Akari & 21 & $591.4 \mathrm{~mL} / 378.5 \mathrm{~L}$ \\
\hline Pyridaben & $75.0 \%$ & Sanmite & 21 & $113.4 \mathrm{~g} / 378.5 \mathrm{~L}$ \\
\hline \multicolumn{5}{|l|}{ Other miticides } \\
\hline Clofentezine & $42.0 \%$ & Ovation & $10 \mathrm{~A}$ & $59.1 \mathrm{~mL} / 378.5 \mathrm{~L}$ \\
\hline Spiromesifen & $45.2 \%$ & Judo & 23 & $118.2 \mathrm{~mL} / 378.5 \mathrm{~L}$ \\
\hline \multicolumn{5}{|l|}{ METI fungicides } \\
\hline Azoxystrobin & $50.0 \%$ & Heritage & 11 & $226.8 \mathrm{~g} /$ Hectare \\
\hline Kresoxim-methyl & $50.0 \%$ & Cygnus & 11 & $45.3 \mathrm{~g} / 378.5 \mathrm{~L}$ \\
\hline Trifloxystrobin & $50.0 \%$ & Compass & 11 & $113.4 \mathrm{~g} / 378.5 \mathrm{~L}$ \\
\hline Untreated control & - & - & - & - \\
\hline Water control & 一 & - & - & - \\
\hline
\end{tabular}

used the adjusted proportions as our response variable in the study. The number of days posttreatment application constituted a repeated measure in an analysis of variance model where treatments and days post-treatment were the main effects in a factorial treatment structure. The repeated measures were on the individual plants with the leaves as sample units or subsamples. The data associated with the four leaves were pooled per plant. Data were analyzed using the PROC MIXED procedure in SAS (Littell et al., 2006) with Kenward-Rogers correction to the denominator $\mathrm{df}$ for correlated errors. If the F-test for an effect was significant at the 0.05 level, we used Fisher's protected least significant difference (LSD) procedure to compare the treatment means among the a.i. treatments and used Dunnett's test to compare the a.i. treatments to the respective controls. All data presented are not corrective.

\section{Results and Discussion}

The results from the study are presented in Tables 2 and 3. The precount mean number of twospotted spider mite nymphs and adults were significant (nymphs: $F=12.54$; df $=9$, 49; $P \leq 0.0001$ and adults: $F=26.00 ; \mathrm{df}=9$, $49 ; P \leq 0.0001$ ), with the mean number of twospotted spider mite nymphs initially on the marigold plants before treatment ranging from 126.4 to 170.2 , and the mean number of adults ranged from 9.0 to 39.6. However, this did not appear to influence the overall results associated with the treatments across the three assessment periods $(3,7$, and $14 \mathrm{~d}$ after application of the treatments) based on the percentage of nymph and adult mortality, and number of live nymphs and adults per treatment (Tables 2 and 3 ).

For the twospotted spider mite nymphs, treatment $(F=5125.07 ; \mathrm{df}=9,40 ; P \leq$ $0.0001)$, day $(F=456.39 ; \mathrm{df}=2,80 ; P \leq$ $0.0001)$, and the treatment $\times$ day interaction $(F=104.99 ; \mathrm{df}=18,80 ; P \leq 0.0001)$ were significant. For the twospotted spider mite adults, treatment $(F=698.45 ; \mathrm{df}=9,40 ; P \leq$ $0.0001)$, day $(F=33.54 ; \mathrm{df}=2,80 ; P \leq$ $0.0001)$, and the treatment $\times$ day interaction $(F=17.36 ;$ df $=18,80 ; P \leq 0.0001)$ were

Table 2. Mean ( \pm SEM) precount, percentage of twospotted spider mite, Tetranychus urticae nymphal mortality per sample (four leaves per plant), and mean number of live nymphs (in parentheses) 3, 7, and $14 \mathrm{~d}$ after application. Also included are the mode of activity (MOA), and FRAC and IRAC mode of action designation codes. There were five replications per treatment.

\begin{tabular}{|c|c|c|c|c|c|c|}
\hline \multirow[b]{2}{*}{ Treatment $^{\mathrm{z}}$} & \multirow[b]{2}{*}{$\mathrm{MOA}^{\mathrm{y}}$} & \multirow[b]{2}{*}{ FRAC/IRAC $\operatorname{code}^{\mathrm{x}}$} & \multirow[b]{2}{*}{ Precount } & \multicolumn{3}{|c|}{ Days after application } \\
\hline & & & & 3 & 7 & 14 \\
\hline Spiromesifen (Judo) & LBI & 23 & $145.6 \pm 5.7$ & $97.5 \pm 0.0 \mathrm{a}^{\mathrm{w}}(3.2)$ & $100.0 \pm 0.0$ a $(0.0)$ & $100.0 \pm 0.0$ a $(0.0)$ \\
\hline Fenpyroximate (Akari) & METI & 21 & $133.2 \pm 1.8$ & $56.4 \pm 2.0 \mathrm{~b}(87.2)$ & $64.8 \pm 2.0 \mathrm{c}(94.4)$ & $79.9 \pm 1.0$ c $(48.2)$ \\
\hline Acequinocyl (Shuttle) & METI & $20 \mathrm{~B}$ & $170.2 \pm 4.2$ & $52.1 \pm 1.0$ c $(106.4)$ & $86.7 \pm 1.0 \mathrm{~b}(27.8)$ & $88.3 \pm 1.0 \mathrm{~b}(20.0)$ \\
\hline Pyridaben (Sanmite) & METI & 21 & $131.8 \pm 3.1$ & $35.2 \pm 2.0 \mathrm{~d}(77.6)$ & $44.6 \pm 1.0 \mathrm{~d}(132.6)$ & $74.9 \pm 1.0 \mathrm{c}(60.2)$ \\
\hline Clofentazine (Ovation) & EI & $10 \mathrm{~A}$ & $133.2 \pm 4.1$ & $5.1 \pm 1.0$ e $(84.2)$ & $6.3 \pm 1.0 \mathrm{f}(95.2)$ & $23.2 \pm 2.0 \mathrm{~d}(171.4)$ \\
\hline Azoxystrobin (Heritage) & METI & 11 & $139.4 \pm 2.1$ & $2.6 \pm 0.0 \mathrm{f}(235.4)$ & $0.0 \pm 0.0 \mathrm{~g}(260.8)$ & $0.0 \pm 0.0 \mathrm{f}(359.4)$ \\
\hline Kresoxim-methyl (Cygnus) & METI & 11 & $138.8 \pm 3.5$ & $2.9 \pm 0.0$ ef $(155.6)$ & $14.3 \pm 0.0$ e $(147.6)$ & $10.9 \pm 0.0$ e $(423.6)$ \\
\hline Trifloxystrobin (Compass) & METI & 11 & $126.4 \pm 1.2$ & $3.3 \pm 0.0$ ef $(180.8)$ & $1.1 \pm 0.0 \mathrm{~g}(251.4)$ & $1.5 \pm 0.0 \mathrm{f}(333.8)$ \\
\hline Water control & - & - & $132.2 \pm 2.2$ & $1.6 \pm 0.0 \mathrm{fg}(134.6)$ & $1.8 \pm 0.0 \mathrm{~g}(111.2)$ & $0.0 \pm 0.0 \mathrm{f}(195.0)$ \\
\hline Untreated control & - & - & $139.8 \pm 3.9$ & $0.0 \pm 0.0 \mathrm{~g}(134.6)$ & $0.0 \pm 0.0 \mathrm{~g}(197.6)$ & $0.0 \pm 0.0 \mathrm{f}(246.6)$ \\
\hline
\end{tabular}

zTreatment: common name or a.i., and trade name (in parentheses).

${ }^{\mathrm{y}} \mathrm{MOA}=$ mode of action, LBI = lipid biosynthesis inhibitor, METI = mitochondria electron transport inhibitor, EI = embryogenesis inhibitor.

${ }^{\mathrm{x}} \mathrm{FRAC}=$ Fungicide Resistance Action Committee; IRAC $=$ Insecticide Resistance Action Committee.

wMeans within a column not followed by a common letter are significantly different $(P \leq 0.005)$ as determined by a Fisher's protected least significant difference (LSD) test. Abbott's corrected mortality was used, but uncorrected data are presented. 
Table 3. Mean ( $($ SEM) percentage of twospotted spider mite, Tetranychus urticae nymphal mortality, and mean number of live adults (in parentheses) associated with the treatments 3, 7, and $14 \mathrm{~d}$ after application. Also included are the mode of activity (MOA), and FRAC and IRAC mode of action designation codes. There were five replications per treatment.

\begin{tabular}{|c|c|c|c|c|c|c|}
\hline \multirow[b]{2}{*}{ Treatment $^{\mathrm{z}}$} & \multirow[b]{2}{*}{$\mathrm{MOA}^{\mathrm{y}}$} & \multirow[b]{2}{*}{ FRAC/IRAC $\operatorname{code} \mathrm{e}^{\mathrm{x}}$} & \multirow[b]{2}{*}{ Precount } & \multicolumn{3}{|c|}{ Days after application } \\
\hline & & & & 3 & 7 & 14 \\
\hline Spiromesifen (Judo) & LBI & 23 & $22.2 \pm 2.3$ & $70.0 \pm 3.0 \mathrm{a}^{\mathrm{w}}(3.2)$ & $87.9 \pm 2.0$ a (2.6) & $85.4 \pm 2.0 \mathrm{a}(2.2)$ \\
\hline Fenpyroximate (Akari) & METI & 21 & $26.0 \pm 2.1$ & $65.6 \pm 2.0 \mathrm{a}(15.8)$ & $61.5 \pm 6.0 \mathrm{~b}(23.0)$ & $66.9 \pm 1.0 \mathrm{~b}(18.8)$ \\
\hline Acequinocyl (Shuttle) & METI & $20 \mathrm{~B}$ & $24.6 \pm 1.4$ & $65.8 \pm 3.0 \mathrm{a}(9.2)$ & $47.8 \pm 3.0 \mathrm{c}(17.2)$ & $61.4 \pm 3.0$ bc $(9.6)$ \\
\hline Pyridaben (Sanmite) & METI & 21 & $15.4 \pm 1.2$ & $11.4 \pm 2.0 \mathrm{~b}(33.2)$ & $34.2 \pm 3.0 \mathrm{~d}(19.6)$ & $57.3 \pm 3.0 \mathrm{c}(12.0)$ \\
\hline Clofentazine (Ovation) & EI & $10 \mathrm{~A}$ & $9.6 \pm 0.5$ & $4.6 \pm 2.0 \mathrm{c}(17.8)$ & $4.0 \pm 2.0$ e $(29.4)$ & $4.7 \pm 1.0$ e $(82.6)$ \\
\hline Azoxystrobin (Heritage) & METI & 11 & $39.6 \pm 2.8$ & $3.6 \pm 1.0$ c $(36.8)$ & $0.4 \pm 0.0$ e $(78.6)$ & $2.2 \pm 1.0$ e $(103.8)$ \\
\hline Kresoxim-methyl (Cygnus) & METI & 11 & $9.0 \pm 1.0$ & $1.1 \pm 1.0 \mathrm{c}(43.8)$ & $3.2 \pm 1.0$ e $(41.2)$ & $17.2 \pm 1.0 \mathrm{~d}(142.0)$ \\
\hline Trifloxystrobin (Compass) & METI & 11 & $37.6 \pm 3.9$ & $2.3 \pm 1.0$ c (73.6) & $3.6 \pm 1.0$ e $(109.4)$ & $1.5 \pm 1.0$ e $(144.2)$ \\
\hline Water control & - & - & $17.8 \pm 1.4$ & $0.0 \pm 0.0 \mathrm{c}(30.8)$ & $1.3 \pm 1.0$ e $(60.6)$ & $0.0 \pm 0.0$ e $(76.6)$ \\
\hline Untreated control & 一 & - & $29.6 \pm 1.7$ & $1.0 \pm 0.0 \mathrm{c}(65.0)$ & $1.0 \pm 0.0$ e $(106.6)$ & $0.0 \pm 0.0$ e $(124.0)$ \\
\hline
\end{tabular}

zTreatment: common name or a.i., and trade name (in parentheses).

${ }^{\mathrm{y}} \mathrm{MOA}=$ mode of action, LBI = lipid biosynthesis inhibitor, METI = mitochondria electron transport inhibitor, EI = embryogenesis inhibitor.

${ }^{x}$ FRAC $=$ Fungicide Resistance Action Committee; IRAC $=$ Insecticide Resistance Action Committee.

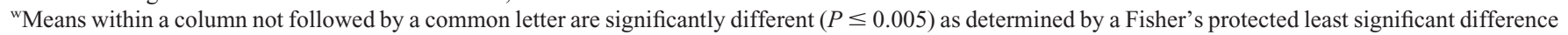
(LSD) test. Abbott's corrected mortality was used, but uncorrected data are presented.

significant. However, it was quite apparent, based on the results, that none of the commercially available $\mathrm{Q}_{\mathrm{o}}$-inhibiting fungicides had any substantial miticidal activity, with percentage of mortality $<18 \%$ for nymphs and adults. This may be affiliated with the fungicide recommended labeled rate (grams per liter or grams per hectare), which is sufficient for controlling certain fungal diseases (e.g., powdery mildew, downy mildew, and/or rusts), but may not be high enough to have any activity on mites. Furthermore, it is possible that the uptake and/or acquisition mechanisms of the miticide or fungicide a.i. are dissimilar enough or intracellular transport of the a.i. is dependent on a specific cross-membrane transporter (A. Jumpponen, personal communication).

The three METI miticides provided some level of control of twospotted spider mite nymphs $14 \mathrm{~d}$ after treatment. However, the miticides were only slightly effective against twospotted spider mite adults, with $<70 \%$ mortality among all three miticides across the three evaluation periods $(3,7$, and 14 $\mathrm{d}$ after treatment) (Tables 2 and 3). Spiromesifen, which is a lipid biosynthesis inhibitor, was most effective against the nymphal and adult stage of the twospotted spider mite, with $>97 \%$ mortality across all three evaluation periods (3, 7, and $14 \mathrm{~d}$ after treatment) for nymphs (Table 2 ) and between $70 \%$ and $86 \%$ mortality across the three evaluation periods (3, 7, and $14 \mathrm{~d}$ after treatment) for adults (Table 3). These results are equivalent to the findings of Cloyd et al. (2009) for the miticides. The METI miticides fenpyroximate and pyridaben were more active on twospotted spider mite nymphs than adults (Tables 2 and 3 ), which is similar to what has been reported by Stumpf and Nauen (2001). The miticide clofentezine failed to induce mortality in either life stage (nymphs or adults) of the twospotted spider mite. This is likely because clofentezine is a growth and embryogenesis inhibitor, and is an ovicide (egg-killing), with activity primarily on spider mite eggs ( $\mathrm{Yu}$, 2008). It is also important to note that any cumulative effect (residual activity) or preexposure of twospotted spider mites to METI fungicides, due to their translaminar activity, may potentially promote resistance developing in twospotted spider mite populations to this mode of action. In conclusion, it appears that the strobilurin-based fungicides have negligible negative effects on the twospotted spider mite, T. urticae.

\section{Literature Cited}

Abbott, W.S. 1925. A method of computing the effectiveness of an insecticide. J. Econ. Entomol. 18:265-267.

Alston, D.G. and S.V. Thomson. 2004. Effects of fungicide residues on the survival, fecundity, and predation of the mites Tetranychus urticae (Acari: Tetranychidae) and Galendromus occidentalis (Acari: Phytoseiidae). J. Econ. Entomol. 97:950-956.

Biggs, A.R. and E.A.C. Hagley. 1988. Effects of two sterol-inhibiting fungicides on populations of pest and beneficial arthropods on apple. Agr. Ecosyst. Environ. 20:235-244.

Bower, K.N., L.P. Berkett, and J.F. Costante. 1995. Nontarget effect of a fungicide spray program on phytophagous and predacious mite populations in a scab-resistant apple orchard. Environ. Entomol. 24:423-430.

Brodsgaard, H.F. and R. Albajes. 1999. Insect and mite pests, p. 48-69. In: van Lenteren, J.C., and Y. Elad (eds.). Integrated pest and disease management in greenhouse crops. Kluwer Academic Publishers, Dordrecht, The Netherlands.

Childers, C.C. and W.R. Enns. 1975. Field evaluation of early season fungicide substitutions on Tetranychid mites and the predators Neoseiulus fallacis and Agistemus fleschneri in two Missouri apple orchards. J. Econ. Entomol. 68: 719-724.

Cloyd, R.A. 2003. Managing insects and mites, p. 113-125. In: Hamrick, D. (ed.). Ball redbook: Crop protection. 17th ed. Ball Publishing, Batavia, IL.

Cloyd, R.A., C.L. Galle, S.R. Keith, and K.E. Kemp. 2009. Evaluation of persistence of selected miticides against the twospotted spider mite, Tetranychus urticae. HortScience 44: 476-480.

Dekeyser, M.A. 2005. Review: Acaricide mode of action. Pest Manag. Sci. 61:103-110.

Delp, C.J. and H.L. Klopping. 1968. Performance attributes of a new fungicide and mite ovicide candidate. Plant Dis. Rep. 52:95-99.

Gisi, U., H. Sierotzki, A. Cook, and A. McCaffery. 2002. Mechanisms influencing the evolution of resistance to $\mathrm{Q}_{\mathrm{o}}$ inhibitor fungicides. Pest Manag. Sci. 58:859-867.

Hollingworth, R.M. and K.I. Ahammadsahib. 1995. Inhibitors of respiratory complex I: Mechanisms, pesticidal actions and toxicology. Rev. Pestic. Toxicol. 3:277-302.

Jeppson, L.R., E.W. Baker, and H.H. Keifer. 1975. Mites injurious to economic plants. University of California Press, Berkeley, CA.

Littell, R., G. Milliken, W. Stroup, R. Wolfinger, and O. Schabenberger. 2006. SAS for mixed models. 2nd edition. SAS Institute, Inc., Cary, NC.

Lord, F.T. 1949. The influence of spray programs on the fauna of apple orchards in Nova Scotia: III. Mites and their predators. Can. Entomol. 81:202-230.

Morgan, C.V.G., N.H. Anderson, and J.E. Swales. 1958. Influences of some fungicides on orchard mites in British Columbia. Can. J. Plant Sci. 38:94-105.

Poe, S.L. and S. McFadden. 1972. Effect of benomyl and surfactants on populations of the twospotted spider mite on dwarf marigold. J. Ga. Entomol. Soc. 7:167-170.

Spadafora, R.R. and R.K. Lindquist. 1972. Ovicidal action of benomyl on eggs of twospotted spider mite. J. Econ. Entomol. 65:1718-1720.

Stumpf, N. and R. Nauen. 2001. Cross-resistance, inheritance, and biochemistry of mitochondrial electron transport inhibitor-acaricide resistance in Tetranychus urticae (Acari: Tetranychidae). J. Econ. Entomol. 94:1577-1583.

van de Vrie, M. 1985. Greenhouse ornamentals, p. 273-283. In: Helle, W., and M.W. Sabelis (eds.). World crop pests: Spider mites. Their biology, natural enemies, and control. Vol. $1 \mathrm{~b}$. Elsevier, Amsterdam, The Netherlands.

van Leeuwen, T., V. Stillatus, and L. Tirry. 2004. Genetic analysis and cross-resistance spectrum of a laboratory-selected chlorfenapyr resistant strain of two-spotted spider mite (Acari: Tetranychidae). Exp. Appl. Acarol. 32:249-261.

Ware, G.W. and D.M. Whitacre. 2004. The pesticide book, 6th ed. MeisterPro Information Resources, Willoughby, $\mathrm{OH}$.

Wistreich, G.A. and M.D. Lechtman. 1984. Microbiology, 4th edition. Macmillan Publishing Company, New York, NY.

Wood, P.M. and D.W. Hollomon. 2003. Review: A critical evaluation of the role of alternative oxidase in the performance of strobilurin and related fungicides acting at the $Q_{0}$ site of complex III. Pest Manag. Sci. 59:499-511.

Yu, S.J. 2008. The toxicology and biochemistry of insecticides. CRC Press, Boca Raton, FL. 